\title{
The Manuscripts and Critical Edition
}

\subsection{The Manuscripts}

Four manuscript copies of the Shukūk are known, three currently housed in the Süleymaniye Library in Istanbul, and one located in Shiraz. ${ }^{1}$ I have obtained copies of all four. What follows is a description of each copy, followed by an introduction to the critical edition.

\section{A MS Istanbul, Hamidiye 1452, ff. $109^{a}-150^{a}$}

An early copy in a composite volume containing miscellaneous philosophical texts, including several epistles by Avicenna, one by each of Ibn al-Haytham and Miskawayh, a short Persian text titled Fawā’id dhakhā’ir al-hikma by Zahīr al-Dīn al-Bayhaqī (d. 565/1170), referred to as Farīd Khurasan (ff. $15^{0^{\mathrm{a}}-15^{2}}$ ), and a short epistle on the differentia ( faṣl) by a certain Sharaf al-Dīn Muhammad

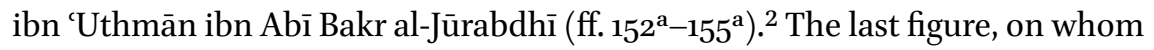
I have found hardly any information in other sources, originates from Jürabdh, a village near Isfarāīn in northern Khurasan, and was alive when the copy was produced. ${ }^{3}$ The volume is undated, but appears to originate from late-6th/12thcentury or early- 7 th/13th-century Khurasan or Transoxania, judging primarily by the style of script and secondarily by its inclusion of al-Bayhaqìs work and association with al-Jūrabdhī. It was produced after al-Mas'ūdī's death, as indicated by the formulaic prayers appended to his name in the incipit and two marginal notes, to be discussed next. The incipit (f. $109^{\text {b }}$ ) goes as follows: ${ }^{4}$

1 References to the three manuscripts in Istanbul are given by Ergin ('İbni Sina Bibliyografyasi', 49; 71), and following him by Brockelmann (GAL Suppl. I, 817). I have also consulted a microfilm copy housed at the Jafet Memorial Library at the American University of Beirut and established that it is a copy of MS A below.

2 In the catalogue of the Hamidiye Library, the volume is listed only as a composite manuscript, without note of its contents (Hamidiye Kütüphanesinde, 78).

3 As is clear from the laudatory formula appended to his name on f. $15^{\mathrm{a}}$. On Jürabdh, see al-Sam‘ānī, Ansāb, 3, 353. A short philosophical commentary on a Prophetic hadīth by alJūrabdhī is also extant, but provides no biographical information on him (MS Istanbul, Ahmet III 1461, ff. $34^{\mathrm{a}}-35^{\mathrm{a}}$ ).

4 I have added dots and hamzas, where appropriate, to the Arabic texts reproduced in this section. No other changes or corrections have been made. 


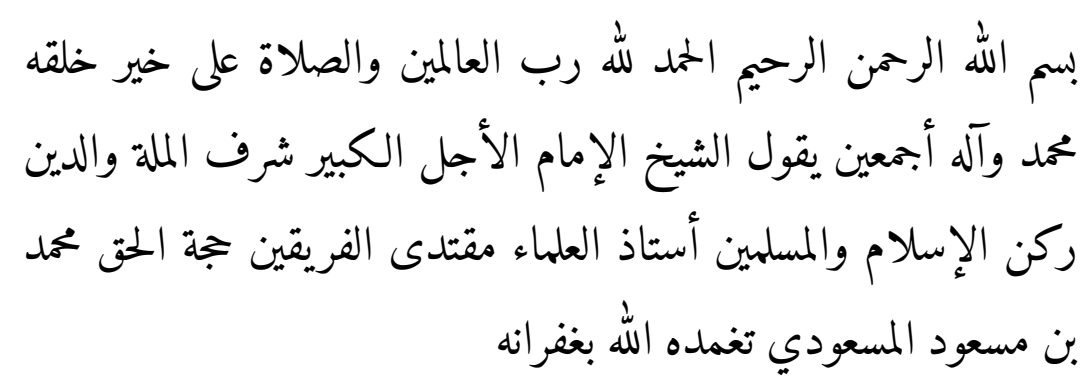

Neither this copy of the Shukūk, nor any of the other texts included in this composite volume is signed off with a colophon.

The copy is executed in curvilinear naskh, with section headings and a diagram inserted in red ink. The margins contain several textual corrections and two collation notes (balaghat, on ff. $13^{\mathrm{b}}$ and $13^{\mathrm{b}}$ ). The copy most probably derives from a non-holograph copy. However, it was collated with a holograph - that is, a copy penned in the author's hand - as indicated by two marginal notes in the copyist's hand, both occurring as glosses on Section 8 . The first, appearing on $\mathrm{f} .135^{\mathrm{a}}$, states that the last five words of a sentence are absent from 'the author's copy': 5

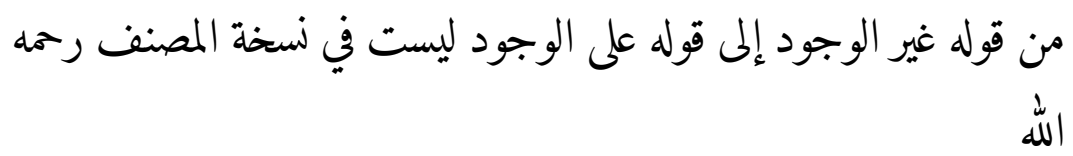

The second note, appearing on $\mathrm{f} .135^{\mathrm{b}}$, states that a lengthy passage is absent from 'the copy in the author's hand': 6

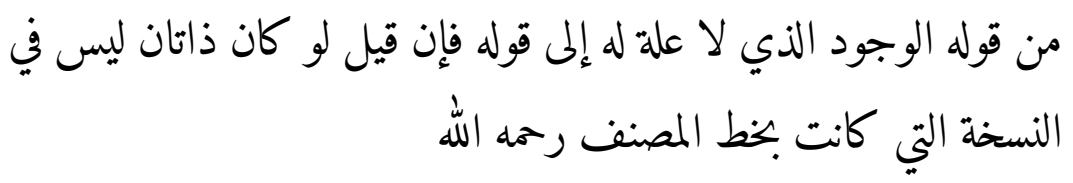

A second note starting on the same page and continuing onto the next page (f. $136^{\mathrm{a}}$ ) is an insertion, which apparently transmits the passage that the copyist found in the author's copy in place of the missing passage, which is approximately four times as long as the insertion. ${ }^{7}$ This indicates that al-Mas'ūdī produced a revised version of the $S h u k \bar{u} k$, and that, assuming that the copyist noted

\footnotetext{
5 Shukūk, 253 .

6 The passage corresponds to $S h u k \bar{u} k, 254.11-258.3$.

7 The insertion is reproduced on p. 255 below.
} 
all the differences that he found between the two versions, the only significant revision was made to this one passage in Section 8. Judging by the contents and length of the two variant passages, I estimate that the longer version, transmitted in the main body of the manuscript text (and in MS B, described next), is the later, revised version, and that the marginal variant transmits an earlier version of the Shukūk.

The title page (f. $\mathrm{l}^{\mathrm{a}}$ ) lists, in a later hand, the texts contained in the composite volume, and gives the title of al-Mas'ūdì's work as Mabāhith wa-shukūk 'alā kitāb al-Ishārāt li-l-Mas'üdì. On f. $109^{\text {a }}$, the title is given as Kitāb al-Mabāhith wa-l-shukūk, and followed with a table of contents for the Shukūk. ${ }^{8}$

\section{B MS Shiraz, Madrasa-'i Imām-i 'Așr, no Number, ff. $1^{b_{-}}{ }^{a}$}

An early copy in a composite volume also containing al-Fārābī's 'Uyūn al-

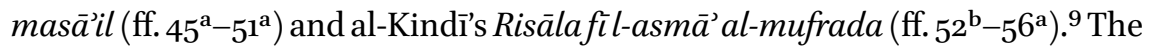
copy is transcribed in an elegant naskh, with section headings inserted in red ink. A table of contents for the Shukūk is provided on f. $1^{\mathrm{b}}$. The title page (f. $2^{\mathrm{a}}$ ) gives the title and the author's name, as follows:

\section{كتاب المباحث والشكوك}

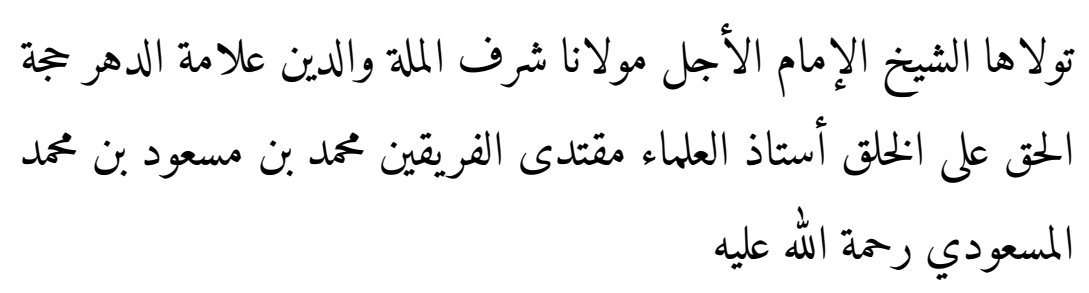

The formula, 'may God's mercy be upon him', following the author's name confirms that the copy was produced after his death. The text begins on $f .2^{b}$ as follows:

$$
\begin{aligned}
& \text { بسم الله الرحمن الرحيم الحمد لله رب العالمين والصاة على خير خلقه محد } \\
& \text { وآله أجمعين يقول محد بن مسعود بن محد المسعودي }
\end{aligned}
$$

8 The Hamidiye collection, to which this manuscript belongs, was originally the library of the Ottomoan sultan Abdülhamid I ( $r .1187 / 1774-1203 / 1889)$, who is named in a bequest statement on the title page (f. $\left.1^{\mathrm{a}}\right)$. However, the manuscript was in Ottoman lands at least since the turn of the fifteenth century, as MS C is derived from it, as I explain below.

9 A facsimile edition of this copy was published by Mīrāth-i Maktūb, Tehran, in 2011. 
According to the copyist's colophon on f. $44^{\text {a }}$, the copy was completed on Thursday, 29 Muharram 605 (13 August 1208), by a certain Mas'ūd ibn Muḥammad ibn 'Alī ibn Muḥtāj al-Gulbarī:

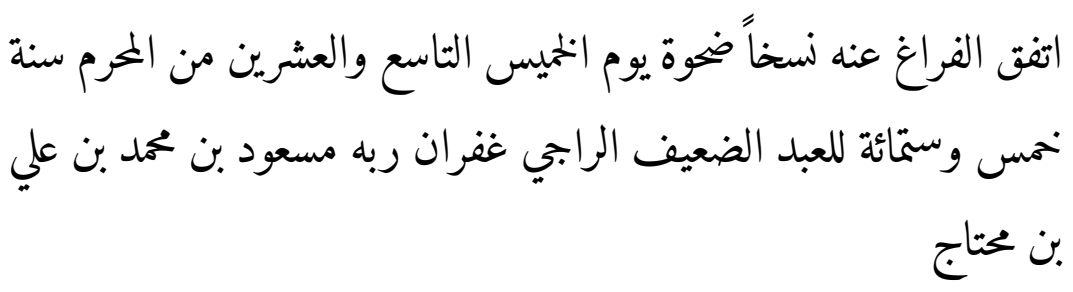

The copyist's name also appears at the end of the two other texts in the volume, hence on $\mathrm{ff} .5^{\mathrm{a}}$ and $56^{\mathrm{a}}$. These are dated, respectively, Wednesday, 8 Dhū l-Qa'da 603 (6June 1207) and Sunday, 11 Ramaḍān 604 (30 March 1208). Folio $1^{\mathrm{a}}$ contains an ownership note belonging to Muhammad ibn Ibrāhīm ibn Yaḥyā al-Shīrāzī, that is, the famous early-seventeenth-century philosopher Mullā Șadrā.

\section{MS Istanbul, Ayasofya $4851, f f \cdot 74^{a_{-121}}{ }^{a}$}

This copy appears in a composite volume, which also contains eight short epistles by Avicenna. The volume is undated, and none of the texts is signed off with a colophon. The title page (f. $\mathrm{r}^{\mathrm{a}}$ ) contains the seals of the Ottoman sultans Bāyezid II (r. 886/1481-918/1512) and Mahmūud I (r. 1143/1730-1168/1754), and a bequest statement naming the latter sultan. The copy was most likely produced for Bāyezid II's library.

The copy is executed in a professional naskh. Some section headings (Sections $1^{-} 3$ and $5^{-8}$ ) are inserted in red ink, but the rest were not written in. Likewise, on $\mathrm{f}$. $91^{\text {b }}$, blank space was left for a diagram, which was not drawn in. Only four corrections, all minor, appear in the margins.

Folio $1^{\text {a }}$ contains the titles of the works included in the composite volume, and includes two mentions of the Shukūk: Kitāb al-Shukūkal-Mas üdì quddisa sirru-hu fi Kitāb al-Ishārāt (sic.) and Kitāb al-Shukūkal-Mas'ūdiyya li-l-Ishārāt. ${ }^{10}$ On f. $74^{\text {a }}$, the title is given as Kitāb al-Shukūkal-Mas'üdiyya 'alā matn al-Ishārāt, and is followed with a table of contents for the text. The text begins on $\mathrm{f.} 74^{\mathrm{b}}$ as follows:

10 I am grateful to Himmet Taşkömür, who has been studying the library of Bāyezid II, for informing me that the former note of the title appears to be in the hand of Khayr al-Din 'Ațūfī (d. 948/1541), the cataloguer of this sultan's library (on him, see Ṭāshköprüzāde, Shaqā’iq, 416-417). 


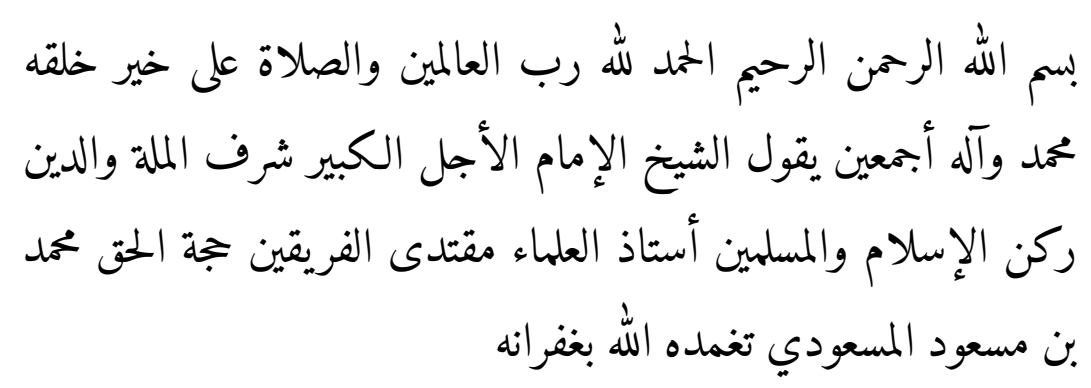

D MS Istanbul, Pertev Paşa 617, ff. $197^{b_{-22}{ }^{b}}$

This copy appears in a composite volume, also containing several other philosophical texts and miscellaneous excerpts in Arabic and Persian. The volume is undated, but is manifestly Ottoman, probably dating to the $15^{\text {th }}$ or 16 th century, judging mainly by the style of script, the paper, and an ownership note for a certain Aḥmad Awḥad al-Dīn Hilmī Zāde on f. $1^{\text {a }}$. The copy is executed in nastaci $q$. No title or table of contents was provided in the original copy. However, a note was added by a later hand in the margin at the beginning of the $S h u k \bar{u} k$, identifying the text as I'tirādāt al-Imām Sharafal-Dīn al-Mas'ūdì 'alā l-Ishārāt, and stating that al-Ṭūsì mentions this work in his commentary on Ishārāt II.1.11. The text begins on $\mathrm{f} .197^{\mathrm{b}}$ as follows:

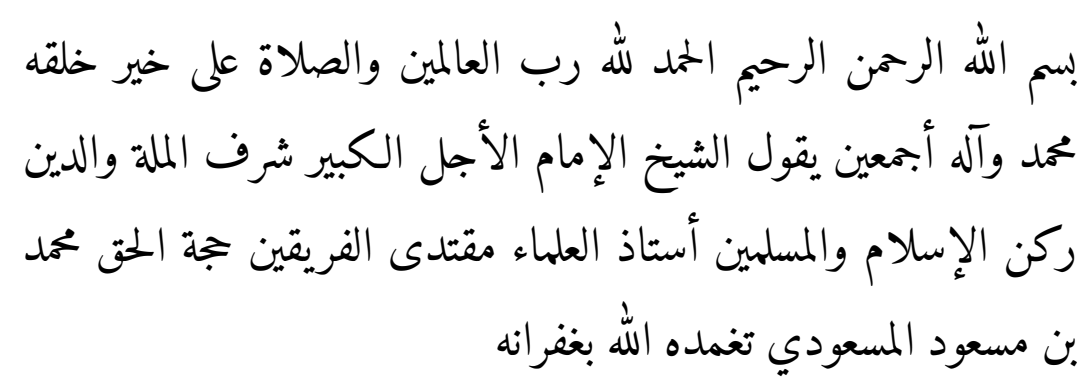

\subsection{Introduction to the Critical Edition}

So, we have two earlier manuscripts, MSS A and B, and two later ones, MSS C and D. And as MSS A, C and D are all located in Istanbul, we have reason to suspect that MSS C and D are derived from MS A, and that the three copies form a closed tradition. This suspicion is confirmed through close comparison between the texts of the three copies. The texts of MSS C and D nowhere improve the text of MS A, and they introduce numerous errors to it. That said, the copyist of $\mathrm{D}$ occasionally attempts to make minor linguistic corrections to the text, but these are all clearly his own and not based on a different witness. 
For instance, he corrects al-mulāqāt al-madhkūr (as in MSS A, B and C) to al-mulāqät al-madhkūra. Given that the errors introduced to the text in MS C differ from those introduced to the text in MS D, neither copy is derived from the other.

Therefore, as the two later copies, MSS C and D, make no improvements to the text, they have not been used for the critical edition. For safe measure, however, we collated our edition extensively with both copies.

This leaves us with the two earlier copies, MSS A and B. As evident from the variants noted in the critical apparatus of our edition, the two manuscripts do not replicate the same textual errors, so neither copy derives from the other. In our critical edition, we have collated both copies and attempted to establish the best text without treating either copy as a base manuscript. As already noted, MS A was collated with a holograph copy, which apparently transmitted an earlier recension of the Shukūk. The only passage where the earlier recension differs significantly from the later recension transmitted in the main body of both copies is a long marginal note, which we have reproduced on p. 255, separately from the main body of our edition. Two minor differences between the two recensions have been noted in the critical apparatus.

We have also collated citations from the Ishärāt with the published edition of this text (ed. S. Dunyā). To give priority to al-Mas'ūdī's own reading of Avicenna's text, we have generally refrained from modifying these citations in conformity with the edition, and have instead noted the variants in the critical apparatus. In at least two places (at the beginnings of Sections 8 and 14), our edition improves the published edition of the Ishärāt. We have also collated the edited text of the Shukūk with citations in al-Rāzī's Jawābāt, and one long passage from Section 4 with a quotation in al-Rāzì's al-Mabăhith al-mashriqiyya, ${ }^{11}$ without note of any variants, as no improvements to the edited text have been made in either case.

Any additions made to the text, most notably the substantive section headings which in the manuscripts only appear in the table of contents, are inserted in square brackets. The text has been modified in accordance with modern spelling conventions, and nunation and diacritical marks have been added where relevant.

11 See p. 4, n. 14 above. 